\title{
Reflection on Rationalization of Public Decision- making from the Perspective of the Administrative Law
}

\author{
Nawei Fu \\ University of Electronic Science and Technology of China \\ Chengdu, China
}

\author{
Weijun Wu \\ University of Electronic Science and Technology of China \\ Chengdu, China
}

\begin{abstract}
As an important activity for the administrative body to carry out public administration, the public decisionmaking involves many aspects of social management and is related with vital interests of administrative relative persons. Only reasonable public decision-making make planning function, organizational function, coordination function, controlling function and other basic functions be better carried out. However, confined to the limitation of recognition, the administrative body is affected by various factors when making public decisions. Therefore, this paper attempts to explore the paths of rationalization of public decision-making from the perspective of the administrative law and discusses the topic from four aspects, namely, risk assessment system, public decision-making process, emergency specification system and post-supervisory mechanism so as to provide some inspirations for rationalization of public decision-making.
\end{abstract}

Keywords-administrative law; risk; public decision-making; rationalization

\section{INTRODUCTION}

Public decision-making is one of processes of public administration, which involves decision-making function, planning function, organizational function, coordination function, controlling function and other basic functions. However, it is placed on the top position among processes of the public administration. Public decision-making refers to decisions made by public organizations during management of social public affairs. From assessment, demonstration, formulation, implementation to post-supervision and evaluation, processes of the public decision-making are throughout the whole public administrative activity.

\section{NECESSity of RATIONALIZATION OF PUbliC DeCision- MAKING}

Research and discussion on public decision-making can be conducive to accelerate and foster the scientific, democratic and legal process of public decision-making of the administrative body and is extremely necessary for improvement of quality of making of public decisions and effective realization of public administration goals. Long-term development of China's economy, social harmony and stability or lasting peace and stability of the country is inseparable from the scientific, democratic and reasonable decision-making.

\section{A. Avoid One-sidedness of Public Decision-making and Improve the Quality of Decision-making}

Under the current China's administrative system, the chief executive responsibility system is the government work responsibility system of administrative management in China. Under the chief executive responsibility system, when making decisions, chief executives of governments and government departments at all levels have the final decision-making power to significant affairs administered by the administrative organization on the basis of democratic discussion and take full charge of the decision-making. Although the chief executive responsibility system is conducive to improve the efficiency of decision-making, it does not mean that the rationality of the decision-making can be neglected or that the decision-making can be specific or arbitrary because the chief executive takes charge of the decision-making. Rationality of the administrative decision-making requires the proceduralization of the decision-making process, which contributes to avoiding one-sidedness of decision-making to some extent. Many regulations on hearing procedure, mass participation and other aspects in the decision-making process can be conducive to draw on collective wisdom, absorb all useful opinions of the masses, carry out synthesized deliberation from different views, positions and interests, finally improve the quality of decision-making and make public decisions relatively satisfy all parties. ${ }^{1}$

\section{B. Promote the Execution Ability of Public Decision-making and Advance the Implementation of Policies}

Without full execution and implementation, scientific public decision-making or good policy-making is impossible to be achieved. In case the public decision-making is unreasonable, without recognition of the public or administrative relative persons, it is difficult for policies to achieve good results only implemented through state machinery and coercive force of the state. The intended effect can be gained only when the public spontaneously and voluntarily support the decision-making. Moreover, reasonable policy-making is usually recognized by the public whose

\footnotetext{
${ }^{1}$ See also Yang Zhenyu. Construction and Internal Legal Basis of Civil Participation in the Government Transformation [M], Beijing: Law Press, Edition 2013.
} 
demands are reflected on the decision-making level through legal means and finally affect the public decision-making. When the public fully participate in making decisions, it is conducive to fully improve the execution ability of public decision-making. The reason is that decisions in which the public participate expand the adoptive scope of policy-making on the basis of full coordination among all parties, absorb wisdom of multiple parties in a larger scope, adopt opinions of multiple parties and are further in line with the interests of most people. ${ }^{2}$ Meanwhile, the public can reflect their values during the participation, which increase their sense of trust and recognition to the administrative body. Therefore, they more consciously support and execute the decisions made by the administrative body and advance the implementation of policies accordingly.

\section{DilemMA OF RATIONALIZATION OF PUBLIC DECISION-} MAKING

\section{A. Gambling between Rationalization and Democratization of Public Decision-making}

As mentioned above, reasonable public decision-making must be democratic decision-making while excessively democratic decision-making is not necessarily reasonable public decision-making because tend towards the interests of people decides that they always produce interference when making decisions. Rationalization of public decision-making is mainly considered from aspects of scientificity and professionalism while the democratization of public decisionmaking is considered from the interest balance among all parties and the universality of participants. The public decision-making mainly involves professional considerations. At this point, the public decision-making will be faced with such dilemmas: in the process of public decision-making, when it merely adopts scientific path model on the basis of professional and scientific knowledge, it will be faced with the legitimate problem of decision-making; when it adopts simple expansion of democratic path model that the public participate in, it will be obsessed with unfavorable consequences caused by numerous participants. That's to say, excessive democracy will make the public decision-making short of professionalism. Readers know that the administrative body is in the neutral position in the public decision-making. All it needs to do is to provide a consultation and communication platform for all parties and arrange interactive dialogue and consultation between groups through the platform. Making of public decisions is inseparable from the negotiation and participation of all parties, but the complexity and uncertainty of public decision-making often make the scope of negotiation larger and can easily lead to the consequences of excessive democracy and lack of professionalism. The professionalism is also an important part affecting the scientificity of public decision-making. It is very necessary for the administrative body to improve the scientificity of public decision-making through utilization of the expert's knowledge. Therefore, it is

2 See also Liu Fuyuan. Weights and Measures of the Administrative Participation - Rule Governance of Open Type Administration [M], Beijing: Law Press, Edition 2012. worthy to discuss the question how to balance the rationalization and democratization of decision-making.

\section{B. Gambling between the Administrative Power and the Legislative Power}

It is well known that public decision-making problem has high complexity and uncertainty. Owing to complex and changeable situations, it is difficult for the public decisionmaking to include the law. The law is forced to confer larger free discretionary power to the administrative body. Therefore, it seems as if the legislative body had the legislative power, faced with unknown dedication that the public decisionmaking is about to face, the legislative body fails to timely update and formulate detailed and comprehensive specifications which the government department can refer to. The legislative body is forced to choose to believe the decision-making ability and risk prevention ability of the administrative body. Therefore, the government has great free discretionary power and the legislative body authorizes the administrative body to organize relevant decision-making subject and grant decision-making power. Expansion of the administrative power leads to excessive power of the administrative body and smaller force of legal regulations when making public decisions, which makes the risk evaluation problem more prominent. To regulate rules on when and how to exercise the legislative power through laws is exactly the premise of the law-based administration. Only on the premise of this can citizens foresee administrative policy and actions that may occur. 3 However, in today's little effect of legal regulation and expansion of legislative power, personnel of the administrative body are mainly comprehensive and compound management talents and they do not have professional knowledge and risk assessment ability. Therefore, it is worthy to discuss the question how to regulate risks of public decision-making in the expansion of legislative power.

\section{Gambling between the Supervisor and the Supervisee}

Supervision is very essential for making of public decisions. The judicial review system is the best way for the law to control the national public power and put the power to the cage of system. The judicial review system is the supervision to the administrative body and the legislative body. Through the judicial review system, it can judge whether the behavior of the administrative body meet the requirements of the Constitution and the law. In the initial period of issuing and implementation of the Administrative Litigation Law of the People's Republic of China in 1989, limitation of the object of judicial review was very prominent because its regulation was only targeted for review on specific administration actions and failed to incorporate abstract administrative actions that have more huge and profound impact on the society into the scope of judicial review. Article 64 in the newly revised Administrative Litigation Law of the People's Republic of China in 2015 stipulates that "When the People's Court hears the administrative cases, in case the normative document stipulated in the Article 53 of the Law is considered to be illegal upon review, it cannot be used as the lawful basis for administrative actions. Moreover, the People's Court should make handling suggestion to the legislative body". When the 
abstract legal act starts to be recognized as the object of the judicial review only in the normative legal documents, it is a progress and breakthrough. Standardization of the judicial review is more prominent that the limitation of the object of the judicial review. How the supervise the behavior of the judicial review, supervisor of makers of public decisions, becomes a major concern. Public decision-making involves a wide range of fields, all of which have their own professional knowledge and are managed by their own professional administrative departments. The administrative trial judges in China do not have very thorough understanding on the problem of scientific policy. Neither can they be experts in relevant scientific and technical problems nor can they properly handle new problems that occur in new fields. When solving controversial issues, they are often be disturbed by the external world.

\section{PATHS OF RATIONALIZATION OF PUBLIC DECISION- MAKING FROM THE PERSPECTIVE OF THE ADMINISTRATIVE LAW}

\section{A. Balance the Rationalization and Democratization of Decision-making and Promote the Scientification of the Decision-making System}

In order to promote the scientification of the decisionmaking system, the administrative body should well prevent against risks of decision-making when making public decisions. The principle of risk prevention is to cast reasonable doubt on the basis of science and technology to some extent and further take preventive measures to reduce or even avoid the production of risks. ${ }^{3}$ The principle of risk prevention requires that decision-makers should take actions under the condition of adequate related evidence information and they should regard existence of risks that need to be prevented as the premise of adoption of preventive measures. To balance the rationalization and democratization of public decisionmaking means to permit the diversification of decision-making subject within certain limits. Diversification of decisionmaking subject does not refer to the meaningless extension of the scope of decision-making subject but that based on quality improvement of decision-making subject, such as diversification of expert think tank, government brain trust and other subjects. Making of decisions needs participation of experts and scholars from different fields and at different standpoints. Advantages of experts and scholars should be taken at the greatest extent on the premise of safeguarding the law-based administration and democracy and on the basis of participation of the public.

\section{B. Balance the Administrative Power and the Legislative Power and Establish the Perfect Decision-making Risk Assessment System}

In order to change the expansion of legislative power and little effect of legislative power of the administrative body, the administrative body should put the law-based administration into practice, establish normative public risk assessment

\footnotetext{
${ }^{3}$ Gao Qinwei. Discussion on the Precautionary Principle of the European Administrative Law [J], Journal of Comparative Law, Iss 3, 2010.
}

system and comprehensively utilize legal means and lawgoverned thought to rise the benefit relationship and behavior relation in the public decision-making risk assessment to the level of legal relation so as to safeguard the scienticification and democracy of risk assessment of public decision-making. Targeted for shapeless establishment of the decision-making risk assessment system and the existence of many problems at current, for example, the decision-making risk assessment becomes mere formality and has strong passiveness and randomness and small coverage; the neutral assessment system combined with self-assessment of assessment administrative body, the participation system of the public and the social supervision system has not yet established, the legislation should be the key power for safeguard of standardization and effectiveness of decision-making of social public risk; results of the public decision-making risk assessment should be actually and fully reflected on the risk regulations so that an insurance for the cage of the power can be added at the source. $5^{4}$ The administrative body should attach importance to safeguard the participation of citizens on the basis of the function of legislation; it should extend the application scope of the hearing system, improve the environment of public opinion survey and feedback and promote the participation awareness and level of the public based on full development of the hearing system stipulated in the previous laws and regulations; it should attach importance to the establishment of expert brain trust, select and cultivate talents in professional fields from professional technology institutions; under the leadership of the administrative department, it should effectively utilize the expert organization consisted of expert teams ; it should perfect the demonstration procedure, carry out the feasibility demonstration and legitimacy demonstration, establish an effective risk assessment agency to concretely undertake the assessment and demonstration work.

\section{Balance the Supervision between the Supervisor and the Supervisee and Intensify the Judicial Review and the External Supervision}

Emphasis on the judicial review of public decision-making is also the need for law-based administration and governance. Article V Clause III in the Constitution of the People's Republic of China explicitly stipulates that "all national institutions, armed forces, parties, social organizations, enterprises and government institutions should abide by the Constitution and the law. Any act in violation of the Constitution and the Law must be investigated." The judicial review system can better safeguard rights of the public. With the acceleration of the process of the legal system, the abstract legal act has been incorporated into the scope of the judicial review. Based on this, authors of this paper suggest the administrative body to further open up the scope of the judicial review and extend the judicial review scope of the abstract legal act. Meanwhile, the administrative body should further improve the comprehensive quality of the administrative judge to lay a good foundation for the judicial review work. Furthermore, it should further intensify the external

\footnotetext{
4 Gao Weiming \& Huang Donghai: Study on the Principle of the Administrative Law and Implementation Means of Risk Regulation [J], Journal of Nanchang University, Iss 3, 2013.
} 
supervision, the supervision of the authority to public decisionmaking of the administrative body and determine the system that important decisions should be reported to or deliberated by the National People's Congress in advance in the legislation; opinions and supervision of experts and scholars should be attached importance to. Owing to the university and complexity of the involved scope of the administrative decision-making, it should attach importance to opinions of experts and scholars of related fields and consciously accept their supervision when making decisions. In addition, it should establish and perfect the administrative assessment law and enhance the assessment and supervision of the public as well as the mass media to the administrative decision-making.

\section{CONCLUSION}

Good public decision-making can benefit people. With popular support of the concept of the law-based administration, the administrative body has heavier responsibility in decisions relevant to national economy, the people's livelihood and social interest. Therefore, it should strictly insist on scientific decision-making and continually improve the quality of administrative decisions so as to benefit people.

\section{REFERENCES}

[1] Yang Zhenyu. Construction and Internal Legal Basis of Civil Participation in the Government Transformation [M], Beijing: Law Press, Edition 2013.

[2] Liu Fuyuan. Weights and Measures of the Administrative Participation - Rule Governance of Open Type Administration [M], Beijing: Law Press, Edition 2012

[3] Jin Zining. Prerequisite Problems of the Risk Administrative Law [J], Journal of the East China University of Political Science and Law, Iss 1, 2014.

[4] Gao Qinwei. Discussion on the Precautionary Principle of the European Administrative Law [J], Journal of Comparative Law, Iss 3, 2010.

[5] Gao Weiming \& Huang Donghai: Study on the Principle of the Administrative Law and Implementation Means of Risk Regulation [J], Journal of Nanchang University, Iss 3, 2013. 